\title{
Adenohypophysial Cell
}

National Cancer Institute

\section{Source}

National Cancer Institute. Adenohypophysial Cell. NCI Thesaurus. Code C45920.

One of five types of secreting cells (somatotrophs, lactotrophs, corticotrophs,

thyrotrophs, and gonadotrophs) found in the anterior lobe of the pituitary gland. 